\title{
Shewanella amazonensis sp. nov., a novel metal-reducing facultative anaerobe from Amazonian shelf muds
}

\author{
Kasthuri Venkateswaran, ${ }^{1,4}$ Michael E. Dollhopf, ${ }^{1}$ Robert Aller, ${ }^{2}$ \\ Erko Stackebrandt ${ }^{3}$ and Kenneth H. Nealson ${ }^{1}$
}

Author for correspondence: Kasthuri Venkateswaran. Tel: +1 6263952994 . Fax: +1 6263952940 .
e-mail: kjvenkat@cco.caltech.edu

1 Center for Great Lakes Studies, University of Wisconsin-Milwaukee, Milwaukee, WI 53204, USA

2 Marine Sciences Research Center, State University of New York, Stony Brook, NY 11794-5000, USA

3 DSMZ, Mascheroder Weg 1b, D-38124 Braunschweig, Germany

4 California Institute of Technology, Dept of Environmental

Engineering, $1200 \mathrm{E}$. California Blvd, Mail Code 138-78, Pasadena, CA 91125, USA

\begin{abstract}
A new bacterial species belonging to the genus Shewanella is described on the basis of phenotypic characterization and sequence analysis of its 165 rRNAencoding and gyrase B (gyrB) genes. This organism, isolated from shallowwater marine sediments derived from the Amazon River delta, is a Gramnegative, motile, polarly flagellated, facultatively anaerobic, rod-shaped eubacterium and has a G+C content of $51.7 \mathrm{~mol} \%$. Strain $\mathrm{SB}^{2} \mathrm{~B}^{\mathrm{T}}$ is exceptionally active in the anaerobic reduction of iron, manganese and sulfur compounds. SB2B' grows optimally at $35{ }^{\circ} \mathrm{C}$, with $1-3 \% \mathrm{NaCl}$ and over a pH range of 7-8. Analysis of the $16 \mathrm{~S}$ rDNA sequence revealed a clear affiliation between strain SB2B' and members of the gamma subclass of the class Proteobacteria. High similarity values were found with certain members of the genus Shewanella, especially with Shewanella putrefaciens, and this was supported by cellular fatty acid profiles and phenotypic characterization. DNA-DNA hybridization between strain SB2B ${ }^{\top}$ and its phylogenetically closest relatives revealed low similarity values (24.6-42.7\%) which indicated species status for strain SB2B'. That SB2B' represents a distinct bacterial species within the genus Shewanella is also supported by gyrB sequence analysis. Considering the source of the isolate, the name Shewanella amazonensis sp. nov. is proposed and strain SB2B' ( $^{\top}$ ( ATCC 700329') is designated as the type strain.
\end{abstract}

Keywords: Shewanella amazonensis sp. nov., metal reduction, gamma Proteobacteria, 16S rRNA, DNA gyrase

\section{INTRODUCTION}

Biogeochemical data have long suggested a significant role for iron and manganese reduction in global nutrient cycling. In recent years, a number of dissimilatory metal-reducing bacteria have been described (see review by Nealson \& Safarini, 1994), and a role for such micro-organisms as catalysts of both manganese and iron reduction in natural systems has been inferred. One of the first bacteria shown to link its

\footnotetext{
Abbreviation: FAME, fatty acid methyl ester.
}

The GenBank accession numbers for the nucleotide sequences in this paper are: S. amazonensis ATCC $700329^{\top}-$ AF005257 (gyrB) and AF005248 (16S rDNA); S. algae ATCC $51192^{\top}-$ AF005686 (gyrB) and AF005249 (16S rDNA); S. benthica ATCC $43992^{\top}$ gyrB, AF014949; S. hanedai ATCC $33224^{\top}$ gyrB, AF005693; S. frigidimarina ACAM 591' gyrB, AF014947; S. gelidimarina ACAM $456^{\top}$ gyrB, AF014946; S. putrefaciens ATCC $8071^{\top}$ gyrB, AF005669; $S$. woodyi ATCC $51908^{\top}$ gyrB, AF014944; Shewanella sp. ANG-SQ1 gyrB, AF014945. respiratory growth to the reduction of metals was Shewanella putrefaciens (Meyers \& Nealson, 1988).

In this paper we describe the isolation of a new metalreducing bacterium of the genus Shewanella from shallow-water marine deposits derived largely from the Amazon River delta off the Amapá coast of Brazil. The Amazon River delta is one of the major sediment depocentres on Earth $(\sim 3-6 \%$ of global riverine sediment supply), and is characterized by unusally extensive zones of sedimentary $\mathrm{Fe}$ and $\mathrm{Mn}$ cycling (Aller et al., 1986, 1996, 1997; Allison et al., 1995; Kuehl et al., 1986). The upper 1-2 $\mathrm{m}$ of delta topset deposits, encompassing a mass of $\sim 20-30 \times 10^{9}$ metric tonnes of sediment, are dominated by non-sulfidic, suboxic redox conditions, with pore-water-dissolved $\mathrm{Fe}^{2+}$ concentrations typically ranging from $\sim 0 \cdot 1-$ $1 \mathrm{mM}$. Samples from the seasonally mobile intertidal deposits at the initiation of this coastal system 
south of Cabo Cassiporé were obtained for the present study.

Strain SB2B ${ }^{T}$ was isolated from Amazonian shelf coastal muds, and is a highly active reducer of iron and manganese oxides, thiosulfate and elemental sulfur. Bacterial isolates showing the properties of Gramnegative motile rods with positive oxidase and catalase reactions, strict respiratory metabolism, ability to reduce a variety of electron acceptors, including trimethylamine $N$-oxide (TMAO), and production of hydrogen sulfide (Stenstrom \& Molin, 1990) have until recently been placed under $S$. putrefaciens. Shewanella was established around its type species $S$. putrefaciens and included Shewanella hanedai (Jensen et al., 1980) and Shewanella benthica (MacDonnell \& Colwell, 1985). Simidu et al. (1990) described Shewanella alga [corrected to Shewanella algae (Trüper \& de' Clari, 1997)] as mesophilic, and relatively high in $\mathrm{G}+\mathrm{C} \%$ content. On the basis of whole-cell protein profiles, ribotyping and 16S rRNA-encoding gene sequence analysis, $S$. algae was recently phylogenetically characterized (Fonnesbech-Vogel et al., 1997).

Conventional phenotypic and chemotaxonomic analyses identified strain $\mathrm{SB} 2 \mathrm{~B}^{\mathrm{T}}$ as $S$. putrefaciens. However, PCR probes designed to recognize $S$. putrefaciens based on $\operatorname{gyr} B$ (encoding the B subunit of DNA gyrase, topoisomerase II) failed to generate a specific amplicon for SB2B ${ }^{\mathrm{T}}$ (data not shown), suggesting that this strain may represent a new species. To elucidate the phylogenetic status of SB2B ${ }^{\mathrm{T}}$, its $16 \mathrm{~S}$ rDNA and gyr $B$ gene sequences were analysed. Both sequences differ from all known shewanellae, suggesting that the organism does indeed deserve the status of new species.

\section{METHODS}

Sample collection. Strain $\mathrm{SB} 2 \mathrm{~B}^{\mathrm{T}}$ was isolated from relatively low salinity (pore water $\mathrm{Cl}^{-} \sim 0 \cdot 1-0 \cdot 2 \mathrm{mM}$ ), mud flat sediment obtained in $\sim 1 \mathrm{~m}$ water, a few kilometres south of Cabo Cassiporé, Amapá, Brazil, on 12 March 1996 (Station $\mathrm{SB} 2 \mathrm{~B}, 03^{\circ} 52.59^{\prime} \mathrm{N}, 51^{\circ} 04 \cdot 30^{\prime} \mathrm{W}$ ). At the time of collection, surface pore-water salinities were relatively low, $\mathrm{Cl}^{-} \sim 0 \cdot 1-$ $0.2 \mathrm{mM}$, but as indicated by the activity of the naturally occurring radionuclide ${ }^{234} \mathrm{Th}\left(t_{1 / 2}=24 \cdot 1 \mathrm{~d}\right)$, these deposits frequently exchange with regions offshore, and thus experience a wide range of salinities over weekly timescales. Pore-water-transport models indicate that the upper few decimetres of sediment are physically mixed by waves and currents over timescales of $<1$ week. Sediment cores were taken manually using CAB tubing $(15 \cdot 2 \mathrm{~cm}$ o.d. $)$, the upper $\sim 50 \mathrm{~cm}$ was placed in $500 \mathrm{ml}$ polyethylene bottles, and then stored in larger wide-mouth glass jars filled with sediment from the same site. Intertidal surface water temperatures along the coast ranged from $\sim 26.4-31.5^{\circ} \mathrm{C}$. Sediment was kept at $\sim 28^{\circ} \mathrm{C}$ except during $\sim 2 \mathrm{~d}$ transport $\left(4^{\circ} \mathrm{C}\right)$.

Bacterial strains. $S$. putrefaciens ATCC $8071^{\mathrm{T}}, S$. algae ATCC $51192^{\mathrm{T}}, S$. hanedai ATCC $33224^{\mathrm{T}}$, S. benthica ATCC $43992^{\mathrm{T}}$, Shewanella woodyi ATCC $51908^{\mathrm{T}}$, Shewanella $\mathrm{sp}$. ANG-SQ1 and Shewanella sp. MR-1 were either purchased from the American Type Culture Collection (ATCC, Rockville, MD, USA) or isolated in our laboratory. Purified DNAs of newly characterized (Bowman et al., 1997) strains, Shewanella frigidimarina ACAM $591^{\mathrm{T}}$ and Shewanella gelidi- marina ACAM $456^{\mathrm{T}}$, were received from the University of Tasmania, Australia. All strains were maintained in semisolid nutrient agar (Difco) and bench cultures were made in either LB liquid or agar media (Sambrook et al., 1989).

Growth conditions. Strain SB2B ${ }^{\mathrm{T}}$ was cultured aerobically in LB liquid medium, and either $10 \mathrm{M} \mathrm{HCl}$ or $10 \%(\mathrm{w} / \mathrm{v})$ $\mathrm{NaOH}$ were used to obtain a $\mathrm{pH}$ range from 5 to 10 . Cultures inoculated in LB liquid medium ( $\mathrm{pH} 7$ ) were incubated at various temperatures under aerobic conditions. The effects of various concentrations of $\mathrm{NaCl}(0-10 \%)$ were studied using $1 \%$ Bacto-tryptone (Difco) as the basal medium. Growth was monitored at appropriate intervals by $\mathrm{OD}_{600}$ measurements with a visible-light spectrophotometer (LKM Biochrom Ultrospec 4050). Anaerobic growth was accomplished in an anaerobic chamber (Coy Laboratory Products) maintained at $2 \%$ hydrogen, the balance in nitrogen.

For visualizing cell shape and flagella, cells were negatively stained with osmium chloride according to the methods of Cole \& Popkin (1981) and then observed with an Hitachi H-600 transmission electron microscope.

Isolation of metal-reducing bacteria. A population of metalreducing bacteria was enriched as described previously (Nealson et al., 1991). Briefly, sediment was mixed with an equal volume of $1.5 \%$ agar containing LM medium supplemented with carbon substrate $\{0.02 \%$ yeast extract, $0.01 \%$ peptone, $0.6 \% \mathrm{NaCl}, 10 \mathrm{mM}$ sodium bicarbonate, $10 \mathrm{mM}$ HEPES, $5 \mathrm{mM}$ lactate, $5 \mathrm{mM}$ succinate, $5 \mathrm{mM}$ glycerol, $1 \mathrm{mM}$ acetate, $0.5 \mathrm{mM}$ ferric chloride, $5 \mathrm{mM}$ sodium molybdate and ferrozine [3-(2-pyridyl)-5,6 bis (4-phenylsulfonic acid)-1,2,4 triazine], $\mathrm{pH} 7 \cdot 2\}$. The vials were sealed off from oxygen and incubated at room temperature; they were monitored daily and scored qualitatively for iron reduction. After a secondary enrichment, samples that showed zones of strong metal reduction were streaked onto plates with similar media, substituting $50 \mathrm{mM}$ ferric citrate for the ferric chloride to isolate single colonies. Appropriate positive (Shewanella sp. MR-1) and negative (Escherichia coli ATCC 25922) controls were performed. Since anaerobic sulfur reduction appears to be a trait associated with the Shewanella species (Moser \& Nealson, 1996), analysis was carried out as per the protocols delineated by Moser \& Nealson (1996).

Measurement of metal reduction. LM growth medium containing $0.6 \% \mathrm{NaCl}$ and $20 \mathrm{mM}$ lactate (Meyers \& Nealson, 1988) was used for metal reduction experiments. Amorphous manganese oxide (Lovely \& Phillips, 1988) and FeOOH (Atkinson et al., 1967) were prepared as described elsewhere. Inocula were grown aerobically in LB liquid medium at $30^{\circ} \mathrm{C}$, harvested by centrifugation, and adjusted to an inoculum size of approximately $2.0 \times 10^{7}$ (equivalent to $\mathrm{OD}_{600}=0 \cdot 2$ ) bacterial cells per $\mathrm{ml}$ in LM medium containing either ferric or manganese oxides. All media and solutions were de-aerated by purging with nitrogen prior to the experiment. Samples $(500 \mu \mathrm{l})$ were drawn at $30 \mathrm{~min}$ intervals, passed through a $0.2 \mu \mathrm{m}$ filter (Millipore) and the resulting soluble (reduced) metal was measured by atomic absorption spectrometry (Burdige \& Nealson, 1986). To determine total $\mathrm{Fe}$ and $\mathrm{Mn}$ concentrations, nitric acid ( $1 \%$ final concentration) was added to the unfiltered samples prior to measurement.

Phenotypic analysis. Routine biochemical tests were carried out according to established procedures (Venkateswaran $e t$ al., 1989; West \& Colwell, 1984). The ability to grow at a $\mathrm{NaCl}$ concentration of $1-10 \%$ was determined in $\mathrm{T}_{1} \mathrm{~N}_{1}$ liquid medium (Venkateswaran et al., 1989), and the ability to grow without $\mathrm{NaCl}$ was determined in $1 \%$ sterile tryptone 
water. Sugars and amino acids were tested on LB broth at a concentration of $1 \%$ as described elsewhere (West \& Colwell, 1984). Haemolytic activity was recorded on Trypticase soy agar supplemented with $5 \%$ defibrinated sheep blood. Additional phenotypical characteristics were determined by the Biolog microbial identification system.

Fatty acid methyl ester (FAME) analysis. Bacteria (SB2B ${ }^{\mathrm{T}}$, ATCC $8071^{\mathrm{T}}$ and ATCC 51192 ) were cultivated in Trypticase soy broth (Difco) overnight at $37^{\circ} \mathrm{C}$. Cellular fatty acids were extracted from dry cells, methylated and analysed by GC (Moss et al., 1974). FAMEs were analysed on a crosslinked $5 \%$ phenyl silicone capillary column $(0.2 \mathrm{~mm}$ i.d. $\times 25 \mathrm{~m}$ long) on a gas chromatograph (HP 5890A; Hewlett-Packard). The column temperature was programmed from 80 to $140^{\circ} \mathrm{C}$ at $20^{\circ} \mathrm{C} \mathrm{min}^{-1}$, then at $3{ }^{\circ} \mathrm{C}$ $\mathrm{min}^{-1}$ to $270^{\circ} \mathrm{C}$, and finally maintained at $270^{\circ} \mathrm{C}$ for $10 \mathrm{~min}$. Injection temperature was $250^{\circ} \mathrm{C}$. The FAME peaks were identified by retention time comparison with authentic FAME standards. Quantification of samples was done by the integration of peak areas.

DNA isolation and characterization. DNA was isolated by chromatography on hydroxyapatite by the procedure of Cashion et al. (1977). The $\mathrm{G}+\mathrm{C}$ content of the DNA was determined by HPLC as described by Mesbah et al. (1989). DNA-DNA hybridization was carried out according to the methods of De Ley et al. (1970), with modifications as described by Huá et al. (1983) and Escara \& Hutton (1980), using a Gilford System 2600 spectrophotometer equipped with a Gilford 2527-R thermoprogrammer and plotter. Renaturation rates were computed by the program TRANSFER.BAS (Jahnke, 1992).

Organisms included in the DNA-DNA hybridization experiments were strain SB2B ${ }^{\mathrm{T}}$ (ATCC $700329^{\mathrm{T}}$ ), $S$. algae ATCC $51192^{\mathrm{T}}, S$. hanedai DSM $6066^{\mathrm{T}}, S$. benthica DSM $8812^{\mathrm{T}}, S$. putrefaciens ATCC $8071^{\mathrm{T}}, S$. woodyi ATCC $51908^{\mathrm{T}}$ and Shewanella sp. ANG-SQ1.

PCR amplification and direct sequencing. Chromosomal DNA from overnight cultures was purified by phenol/ chloroform extraction and ethanol precipitation (Johnson, 1981). Purified genomic DNA was used as template for PCR amplification. PCR assays were performed in a DNA Thermal Cycler (Perkin Elmer). The $1.2 \mathrm{~kb}$ gyr $B$ gene (Yamamoto \& Harayama, 1995) and the $1.5 \mathrm{~kb}$ smallsubunit rDNA (Ruimy et al., 1994) were amplified as per established protocols.

The identities of the fragments were verified by sequencing from both ends using the DyeDeoxy chain-termination method with the Sequenase DNA sequencing kit (United States Biochemical) and by ABI 373A automatic sequencing as described by the manufacturer (Perkin-Elmer). DNA sequences were determined from both strands by extension from the $\mathrm{N}$ - and $\mathrm{C}$-terminal ends using universal primers (Ruimy et al., 1994; Yamamoto \& Harayama, 1995) and followed by primer walking.

Phylogenetic analysis and alignment. The 16S rDNA sequence was compared with about 500 other 16S rDNA sequences already available in GenBank for their phylogenetic relationships. The gyr $B$ sequence was compared with 150 other $\operatorname{gyr} B$ sequences that were retrieved from the ICB database (http://www.mbio.co.jp). Evolutionary trees were constructed with the PAUP program for Macintosh (Swofford, 1990) and the ARB program package for the Sun Microstation (Strunk \& Ludwig, 1995), using the maximumlikelihood analysis method.

\section{RESULTS AND DISCUSSION}

\section{Morphological characteristics}

Strain SB2B ${ }^{\mathrm{T}}$ (=ATCC $700329^{\mathrm{T}}$ ) is a Gram-negative, rod-shaped, non-spore-forming organism. It grows well at $35^{\circ} \mathrm{C}$ in standard bacteriological nutrient media such as LB or Trypticase soy broth supplemented with $1 \% \mathrm{NaCl}$. Cells are 2 to $3 \mu \mathrm{m}$ in length and $0.4-0.7 \mu \mathrm{m}$ in diameter, and are motile by a single unsheathed polar flagellum. On LB agar incubated at $35^{\circ} \mathrm{C}$, young colonies are circular, with a diameter of 1-2 mm, smooth, convex, and slightly pinkish, with regular edges, similar to those of $S$. putrefaciens and $S$. algae. Neither diffusible pigments nor bioluminescence was observed.

\section{Physiological properties}

Biochemical characterization of $\mathrm{SB} 2 \mathrm{~B}^{\mathrm{T}}$ is presented in Table 1. Type strains of $S$. putrefaciens (ATCC $8071^{\mathrm{T}}$ ) and $S$. algae (ATCC 51192 ${ }^{\mathrm{T}}$ ) were included to compare the physiological traits of strain SB2B ${ }^{\mathrm{T}}$. Strain SB2B ${ }^{\mathrm{T}}$ was positive for cytochrome oxidase, catalase and gelatinase, and negative for the production of amylase, lipase, alginase, arginine dihydrolase and decarboxylases of lysine and ornithine. It reduced nitrate to nitrite and nitrogen gas was formed from nitrite. Strain SB2 $B^{T}$ was unable to ferment glucose but reduced TMAO and produced hydrogen sufide. Indole and ketoine were not produced by this strain. As with $S$. algae strains, sheep blood cells were haemolysed by SB2 $B^{\mathrm{T}}$. The carbon substrate profile of $\mathrm{SB} 2 \mathrm{~B}^{\mathrm{T}}$ as measured by the Biolog system showed an identification match for S. putrefaciens. Phenotypically, SB2B ${ }^{\mathrm{T}}$ resembles $S$. algae more than $S$. putrefaciens (Table 1). Of the 48 properties tested, nine were different from those of $S$. putrefaciens and only four were different from $S$. algae. Growth at $40{ }^{\circ} \mathrm{C}, \mathrm{N}_{2}$ gas production from nitrite, gelatinase production and haemolysis of sheep blood cells were the characteristic features that could differentiate SB2B ${ }^{\mathrm{T}}$ from $S$. putrefaciens. S. algae cells did not exhibit any growth when grown at $4{ }^{\circ} \mathrm{C}$ for $24 \mathrm{~h}$. Strain SB2B $\mathrm{B}^{\mathrm{T}}$ did not grow at $\mathrm{NaCl}$ concentration more than $3 \%$. These phenotypic characters were useful to differentiate strain SB2B ${ }^{\mathrm{T}}$ from $S$. putrefaciens and $S$. algae.

Phenotypic characteristics, such as positive oxidase and catalase reactions, the absence of glucose fermentation, a strict respiratory metabolism, the ability to reduce a variety of electron acceptors, including TMAO, and the production of hydrogen sulfide seem to be sufficient to warrant the inclusion of $S B 2 B^{T}$ in the genus Shewanella.

\section{Optimum growth conditions}

SB2 $B^{T}$ grew between 4 and $45^{\circ} \mathrm{C}$, with optimum growth at $37^{\circ} \mathrm{C}$, and over the $\mathrm{pH}$ range of 6-9 (optimum 7-8). Although growth was seen in the absence of $\mathrm{NaCl}$, growth yield was high in $1 \% \mathrm{NaCl}$. 
Table 1. Differential biochemical characterization of S. amazonensis

All strains are straight rods, Gram-negative; grow at $35^{\circ} \mathrm{C}$ in marine agar, 1 or $3 \% \mathrm{NaCl}$ and $\mathrm{pH} 6-10$; they do not grow at $\mathrm{pH} 5$ or $>10$; positive for production of oxidase, catalase and $\mathrm{H}_{2} \mathrm{~S}$ from thiosulfite. Reduce nitrate to nitrite; negative for production of chitinase, alginase, amylase, arginine dihydrolase, lysine and ornithine decarboxylase, indole, $\alpha$-ketoine and diffusible pigment; utilizes D-mannose, D-fructose, DL-lactate, L-serine as sole carbon source; do not utilize sucrose, maltose, D-mannitol, glycerol, D-sorbitol, DL-malate, putrescine and L-histidine as sole carbon source. + , Positive reaction; - , negative reaction.

\begin{tabular}{|c|c|c|c|}
\hline Characteristic & $\begin{array}{l}\text { S. amazonensis } \\
\text { ATCC 700329T }\end{array}$ & $\begin{array}{c}\text { S. putrefaciens } \\
{\text { ATCC } 8071^{\mathrm{T}}}^{\text {ATC }}\end{array}$ & $\begin{array}{c}\text { S. algae } \\
{\text { ATCC } 51192^{\mathrm{T}}}^{\text {ATC }}\end{array}$ \\
\hline \multicolumn{4}{|l|}{ Growth: } \\
\hline $4^{\circ} \mathrm{C}$ & + & + & $-{ }^{*}$ \\
\hline $40^{\circ} \mathrm{C}$ & + & - & + \\
\hline $0 \% \mathrm{NaCl}$ & Weak & + & - \\
\hline $6 \% \mathrm{NaCl}$ & - & + & + \\
\hline $10 \% \mathrm{NaCl}$ & - & - & + \\
\hline $\mathrm{NO}_{2}$ to $\mathrm{N}_{2}$ & + & - & + \\
\hline Gelatinase production & + & - & + \\
\hline Haemolysis of sheep blood cells & + & - & + \\
\hline \multicolumn{4}{|l|}{ Sole carbon source: } \\
\hline Lactose & - & + & - \\
\hline Succinate & + & - & + \\
\hline Fumarate & + & - & - \\
\hline Citrate & + & - & $+1-$ \\
\hline $\mathrm{G}+\mathrm{C}$ content $(\mathrm{mol} \%)$ & $51 \cdot 7$ & $47 \cdot 0$ & $52 \cdot 4$ \\
\hline
\end{tabular}

* No growth in $24 \mathrm{~h}$.

Table 2. Fatty acid composition of various Shewanella species

\begin{tabular}{|c|c|c|c|}
\hline \multirow[t]{2}{*}{ Fatty acid } & \multicolumn{3}{|c|}{ Percentage composition of fatty acids in: } \\
\hline & $\begin{array}{l}\text { S. amazonensis } \\
\text { ATCC } 700329^{\mathrm{T}}\end{array}$ & 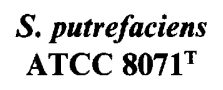 & $\begin{array}{c}\text { S. algae } \\
\text { ATCC 51181 }\end{array}$ \\
\hline \multicolumn{4}{|c|}{ Straight-chain fatty acids: } \\
\hline $14: 0$ & 1.43 & $2 \cdot 31$ & $1 \cdot 32$ \\
\hline $15: 0$ & $9 \cdot 17$ & $3 \cdot 17$ & $6 \cdot 51$ \\
\hline $16: 0$ & $6 \cdot 11$ & $19 \cdot 05$ & $16 \cdot 81$ \\
\hline $17: 0$ & 3.95 & $1 \cdot 54$ & $4 \cdot 07$ \\
\hline $18: 0$ & $0 \cdot 10$ & $2 \cdot 10$ & $0 \cdot 39$ \\
\hline \multicolumn{4}{|c|}{ Unsaturated tertiary-branched fatty acids: } \\
\hline 13:0-iso & $4 \cdot 70$ & $2 \cdot 50$ & $0 \cdot 50$ \\
\hline $14: 0$-iso & $1 \cdot 55$ & $0 \cdot 25$ & $1 \cdot 40$ \\
\hline $15: 0$-iso & 26.69 & $21 \cdot 12$ & $27 \cdot 39$ \\
\hline $16: 0$-iso & $1 \cdot 41$ & $0 \cdot 13$ & $0 \cdot 51$ \\
\hline $17: 0$-iso & $1 \cdot 80$ & 1.65 & 1.43 \\
\hline \multicolumn{4}{|c|}{ Monoenoic cyclopropyl fatty acids: } \\
\hline $15: 1 \omega 6 c$ & 0.83 & $0 \cdot 19$ & $0 \cdot 16$ \\
\hline $16: 1 \omega 7 c$ & $14 \cdot 65$ & $29 \cdot 57$ & $15 \cdot 28$ \\
\hline $16: 1 \omega 9 c$ & 0.69 & $3 \cdot 53$ & $2 \cdot 82$ \\
\hline $17: 1 \omega 6 c$ & $2 \cdot 43$ & 0.95 & 0.92 \\
\hline $17: 1 \omega 8 c$ & $23 \cdot 45$ & $6 \cdot 70$ & $10 \cdot 87$ \\
\hline $18: 1 \omega 7 c$ & $4 \cdot 46$ & $5 \cdot 96$ & $5 \cdot 16$ \\
\hline $18: 1 \omega 9 c$ & $1 \cdot 39$ & $3 \cdot 78$ & 4.95 \\
\hline
\end{tabular}




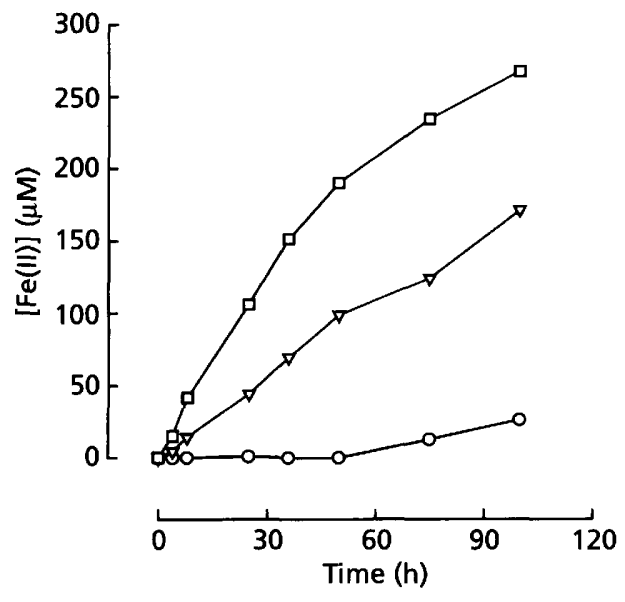

Fig. 1. Amorphous $\mathrm{Fe}(\mathrm{III})$ oxide reduction by $S$. amazonensis ATCC $700329^{\top}(\square)$, Shewanella sp. MR-1 $(\nabla)$ and a control with no cells $(O)$. Experiments were conducted at room temperature $\left(23^{\circ} \mathrm{C}\right)$ in $\mathrm{LM}$ medium supplemented with $0.6 \% \mathrm{NaCl}$ at $\mathrm{pH} 7.2$ under anaerobic conditions $\left(98 \% \mathrm{~N}_{2}\right.$ and $\left.2 \% \mathrm{H}_{2}\right) ; 400 \mu \mathrm{M}$ FeOOH with $20 \mathrm{mM}$ lactate (Atkinson et al., 1967) was used as the sole electron acceptor. Approximately $2.0 \times 10^{7}$ (equivalent to $\mathrm{OD}_{600}=0.2$ ) bacterial cells $\mathrm{ml}^{-1}$ were added. All media and solutions were de-aerated prior to starting the experiment. Samples $(500 \mu \mathrm{l})$ were drawn at appropriate intervals in triplicate and passed through a $0.2 \mu \mathrm{m}$ filter, and then added to $4.5 \mu l 1 \%$ nitric acid. Atomic absorption spectroscopy was used to measure the reduced soluble Fe(II).

Being isolated from the intertidal zone, $\mathrm{SB} 2 \mathrm{~B}^{\mathrm{T}}$ might be adapted to the salty environment.

\section{Cellular fatty acid composition}

Fatty acid compositions of strain SB2B ${ }^{\mathrm{T}}, S$. putrefaciens ATCC $8071^{\mathrm{T}}$ and $S$. algae ATCC 51181 are shown in Table 2 . SB2B ${ }^{T}$ contains straight chain, unsaturated tertiary branch, and monoenoic cyclopropyl fatty acids with a composition of $20 \cdot 7,36 \cdot 1$ and $47.9 \%$, respectively. Among the fatty acids measured, SB2 ${ }^{\mathrm{T}}$ was found to contain three major fatty acids, namely $15: 0$-iso $(26.7 \%), 17: 1 \omega 8 c(23.5 \%)$, and $16: 1 \omega 7 c(14 \cdot 7 \%)$. Many of the fatty acids present in SB2B ${ }^{T}$ are the same as that of $S$. putrefaciens and S. algae.

Although some key characteristics differentiate strain SB2B ${ }^{\mathrm{T}}$ from other species of Shewanella, conventional biochemical testing and FAME profiles place $S B 2 B^{T}$ within the $S$. putrefaciens-S. algae group.

\section{Metal reduction}

Fig. 1 illustrates the reduction of ferric oxide by strain $S B 2 B^{T}$ and its metal-reducing activity relative to that of the well-studied Shewanella sp. MR-1 (Nealson \& Saffarini, 1994). When microcosms were incubated anaerobically at room temperature with ferric oxide as the terminal electron acceptor, a threefold increase in soluble iron was found at $8 \mathrm{~h}$ in the microcosm

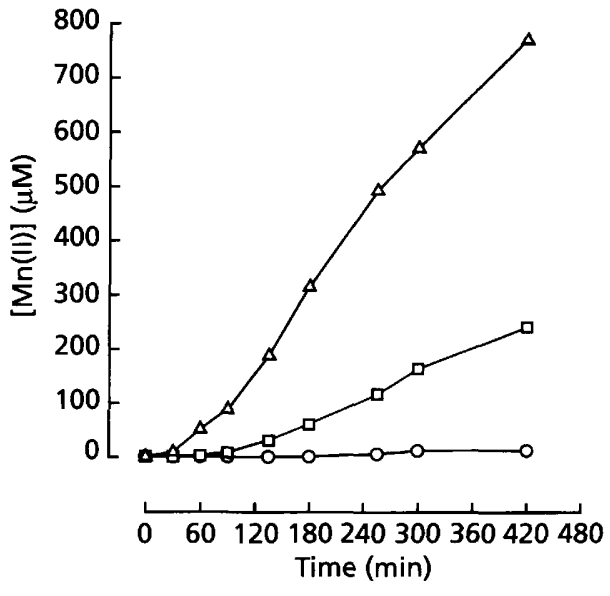

Fig. 2. Amorphous manganese oxide reduction by $S$. amazonensis ATCC $700329^{\top}(\square)$, Shewanella sp. MR-1 $(\nabla)$ and a control with no cells (O). Experimental and analytical conditions were as described in Fig. 1 where Fe(III) oxide was replaced with $1000 \mu \mathrm{M}$ manganese oxide.

containing SB2B ${ }^{T}$ compared with MR-1. The release of free iron by SB2B ${ }^{\mathrm{T}}$ was twice that of MR-1 between 25 and $75 \mathrm{~h}$ and $1 \cdot 5$-fold greater, even after $100 \mathrm{~h}$.

Manganese reduction by strain $\mathrm{SB} 2 \mathrm{~B}^{\mathrm{T}}$ is depicted in Fig. 2. When microcosms were incubated anaerobically at room temperature with manganese oxide as the terminal electron acceptor, the initial release of soluble manganese by $\mathrm{SB} 2 \mathrm{~B}^{\mathrm{T}}$ was 18 -fold greater than that of MR-1. The release of free manganese in SB2B ${ }^{T}$ microcosms was still six- and fourfold greater than that noted for MR-1 after 2 and $4 \mathrm{~h}$, respectively, and threefold after $7 \mathrm{~h}$ incubation.

SB2 ${ }^{T}$ was streaked onto sulfur-containing plates and incubated anaerobically. Both SB2B ${ }^{\mathrm{T}}$ and Shewanella sp. MR-1 showed activity on solid agar plates but the zone of sulfur clearing was wider for SB2B ${ }^{\mathrm{T}}$. It was difficult to determine if SB2B ${ }^{\text {T }}$ had higher sulfur reduction activity per se, as this method is purely qualitative.

\section{Molecular phylogenetic analysis}

As SB2B ${ }^{\mathrm{T}}$ was identified as $S$. putrefaciens by both conventional phenotypic and chemotaxonomies, we originally thought that this bacterium was $S$. putrefaciens. While we have screened hundreds of shewanellae against $S$. putrefaciens-specific gyrB probes, no PCR amplification product was observed for SB2B ${ }^{T}$ (data not shown). This lead us to perform a phylogenetic analysis of SB2B ${ }^{\mathrm{T}}$. In addition, this strain is a more active metal reducer than any of the other shewanellae we have studied.

The phylogenetic position of SB2 $B^{\mathrm{T}}$ was examined by comparing its 16S rDNA sequence with those of various eubacterial phyla (Woese, 1987). All phylogenetic analyses of its 16S rDNA sequence un- 


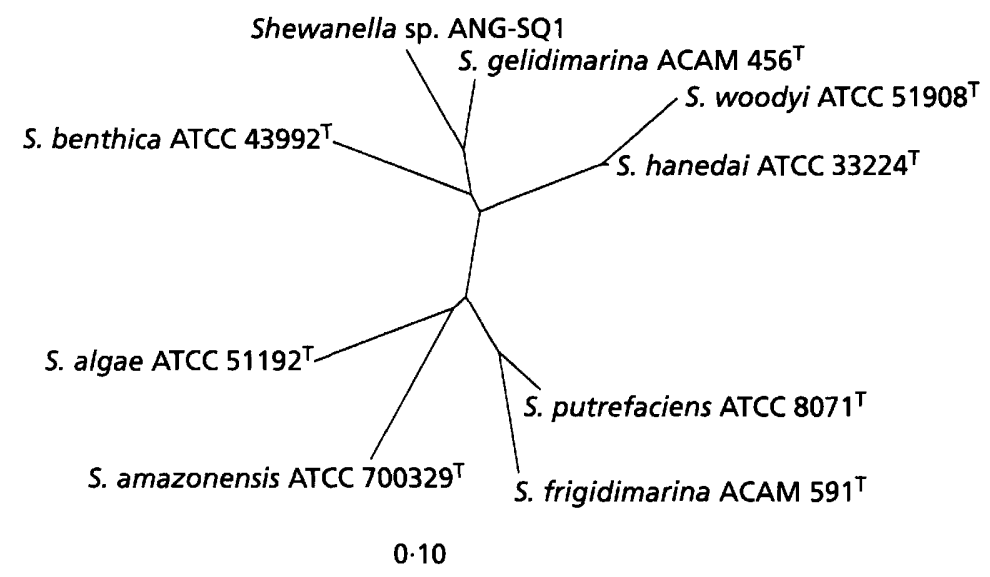

Fig. 3. Phylogenetic position of $S$. amazonensis ATCC $700329^{\top}$ based on $16 \mathrm{~S}$ rDNA nucleotide sequences. An unrooted phylogenetic tree was obtained by performing a maximum-likelihood analysis.

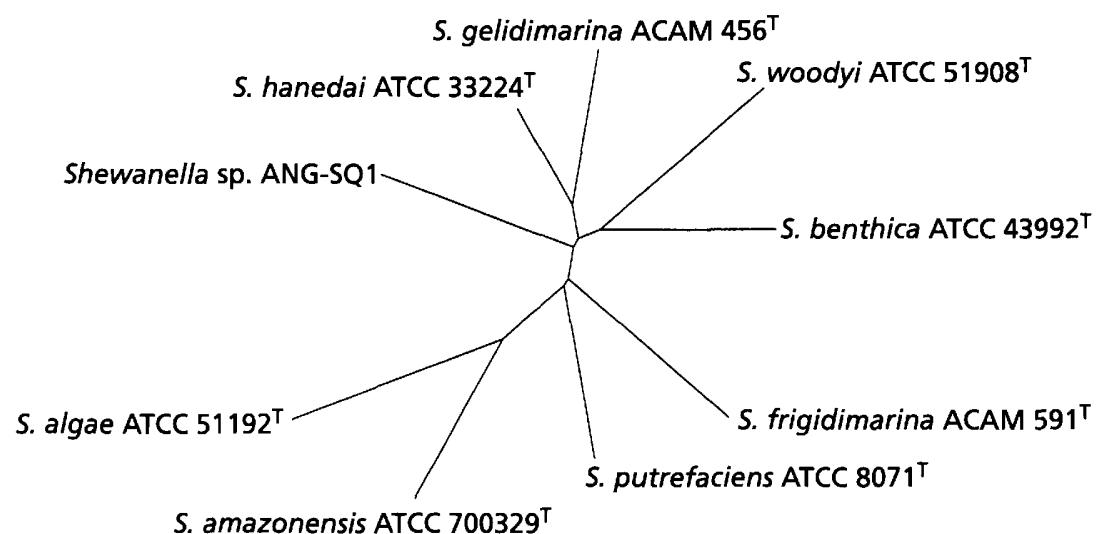

S. amazonensis ATCC $700329^{\top}$
Fig. 4. Phylogenetic tree of $S$. amazonensis ATCC $700329^{\top}$ based on gyrB nucleotide sequences by maximum-likelihood analysis. ambiguously demonstrated that $\mathrm{SB} 2 \mathrm{~B}^{\mathrm{T}}$ belonged to the gamma subclass of the class Proteobacteria. The 16S rDNA sequences of all known gamma Proteobacteria were compared with that of SB2B ${ }^{\mathrm{T}}$. Their phylogenetic relationships were then analysed, and this study was repeated with several different subdomains of the 16S rDNA sequence and bootstrapping analysis was performed to avoid sampling artifacts. Both 16S rDNA and gyrB nucleotide sequences of SB2 ${ }^{\mathrm{T}}$ indicate that it shares a close phylogenic relationship with the species of Shewanella, Alteromonas and Vibrio.

Neighbour-joining, parsimony and maximum-likelihood analyses were then undertaken on this subset of bacteria, using several subdomains of the 16S rDNA. The results of these analyses are summarized in Fig. 3. In all analyses, SB2 ${ }^{\mathrm{T}}$ was most closely associated with members of the genus Shewanella. When we were preparing this manuscript, only five Shewanella species had been formally described, namely $S$. putrefaciens, $S$. hanedai, S. benthica, $S$. algae and $S$. colewelliana (MacDonnell \& Colwell, 1985; Fonnesbech-Vogel et al., 1997). However, GenBank contains 16S rDNA sequences for eight Shewanella species. This includes the above four well-described species (ATCC 8071 ,
$33224^{\mathrm{T}}, 43992^{\mathrm{T}}, 51192^{\mathrm{T}} ;$ S. colwelliana sequence is not available), two recently described Antarctic sea ice isolates (ACAM 456 ${ }^{\mathrm{T}}, 591^{\mathrm{T}}$; Bowman et al., 1997), one squid isolate (ANG-SQ1), and one new luminous isolate (ATCC 51908 ${ }^{\mathrm{T}}$; Makemson et al., 1997). The $16 \mathrm{~S}$ rDNA sequence of SB2B ${ }^{\mathrm{T}}$ was compared with the eight other Shewanella species. Variation of 16S rDNA nucleotide sequences of SB2B $B^{\mathrm{T}}$ and type strains of $S$. algae, S. benthica, $S$. frigidimarina, $S$. gelidimarina, $S$. hanedai, S. putrefaciens, $S$. woodyi and Shewanella $\mathrm{sp}$. ANG-SQ1 was $7 \cdot 1,8 \cdot 8,8 \cdot 1,7 \cdot 9,8 \cdot 7,6 \cdot 3,9 \cdot 0$ and $7 \cdot 9 \%$, respectively.

Nucleotide sequences of the $\operatorname{gyr} B$ genes of eight Shewanella strains described above along with SB2B ${ }^{\mathrm{T}}$ were determined. A phylogenetic tree based on $\operatorname{gyr} B$ nucleotide sequences is shown in Fig. 4. Variation of gyr $B$ nucleotide sequences of $\mathrm{SB} 2 \mathrm{~B}^{\mathrm{T}}$ and type strains of $S$. algae, $S$. benthica, $S$. frigidimarina, $S$. gelidimarina, S. hanedai, S. putrefaciens, S. woodyi and Shewanella sp. ANG-SQ1 was 19.5, 22.1, 23·7, 23.9, $22 \cdot 6,20 \cdot 9,25 \cdot 8$ and $24 \cdot 7 \%$, respectively. Unlike the situation with the $16 \mathrm{~S}$ rDNA, variation between $\operatorname{gyr} B$ genes was very high $(>20 \%)$. A very high $25 \cdot 8 \%$ variation was noted between strain $\mathrm{SB} 2 \mathrm{~B}^{\mathrm{T}}$ and $S$. woodyi ATCC $51908^{\mathrm{T}}$. The conclusions drawn from 
gyr $B$ sequence analysis are consistent with those drawn from $16 \mathrm{~S}$ rDNA analysis. Hence, strain $\mathrm{SB}_{2} \mathrm{~B}^{\mathrm{T}}$ is distinct and deserves the status of a new species.

Analysis of both 16S rDNA and gyrB sequences results in compelling information about the taxonomic position of $\mathrm{SB} 2 \mathrm{~B}^{\mathrm{T}}$. This bacterium displays a nonambiguous affiliation with the gamma subclass of the Proteobacteria. The closest relatives for which a $16 \mathrm{~S}$ rDNA and $\operatorname{gyr} B$ sequence data are presently available are $S$. putrefaciens and $S$. algae, but it is not possible to determine a significant match to any known bacterium.

Strain SB2B ${ }^{\mathrm{T}}$ has a $\mathrm{G}+\mathrm{C}$ content of $51.7 \mathrm{~mol} \%$, which does not fall within the range that is typical of $S$. putrefaciens ( $43-47 \mathrm{~mol} \%$ ) whereas the $\mathrm{G}+\mathrm{C}$ content of $S$. algae is in this range (Fonnesbech-Vogel et al., 1997). Strain SB2B ${ }^{\mathrm{T}}$ shares $94 \%$ and less similarity with any of the Shewanella species for which 16S rDNA sequences have been deposited. At this level of relatedness, affiliation of this strain to any of the Shewanella species is unlikely as demonstrated by Stackebrandt \& Goebel (1994). Nevertheless, to confirm the separate species status of strain SB2B ${ }^{\mathrm{T}}$, DNA-DNA hybridization studies were performed (Table 3) between this strain and Shewanella species: $S$. algae ATCC $51192^{\mathrm{T}}$, S. benthica DSM $8812^{\mathrm{T}}, S$. hanedai DSM $6066^{\mathrm{T}}, S$. putrefaciens ATCC $8071^{\mathrm{T}}, S$. woodyi ATCC $51908^{\mathrm{T}}$ and Shewanella sp. ANG-SQ1. The highest value of $42.7 \%$ was determined for the pair SB2B ${ }^{\mathrm{T}}$ and $S$. putrefaciens ATCC $8071^{\mathrm{T}}$. This value is significantly below the $70 \%$ similarity level, recommended as the threshold value for species delineation (Wayne et al., 1987). Similarity values for strain $\mathrm{SB} 2 \mathrm{~B}^{\mathrm{T}}$ and the other species ranged between 25 and $40 \%$. It can thus be concluded on the basis of moderate 16S rDNA and DNA-DNA similarity values that strain $\mathbf{S B} 2 \mathbf{B}^{\mathrm{T}}$ represents a novel species within the genus Shewanella.

Though many Shewanella isolates share common phenotypic traits, the 16S rDNA (Fonnesbech-Vogel et al., 1997) and DNA-DNA hybridization studies (Owen et al., 1978; Semple \& Westlake, 1987) have revealed the obvious heterogeneity of various strains that have been grouped within the $S$. putrefaciens group. This paper also supports the fact that without nucleotide sequence analysis, strain $\mathrm{SB} 2 \mathrm{~B}^{\mathrm{T}}$ would have been placed within $S$. putrefaciens.

\section{Description of the Shewanella amazonensis sp. nov.}

Shewanella amazonensis (ama.zo.nen.sis. M.L. n. amazonensis named after the area from which the bacterium was collected).

Cells of the type strain are rod-shaped, $2-3 \mu \mathrm{m}$ in length and $0.40 .7 \mu \mathrm{m}$ in diameter, Gram-negative, facultatively anaerobic, polarly flagellated. No endospores nor capsules are formed. Peritrichous flagellation is not observed when the organism is cultivated on solid media. Colonies on LB agar medium are circular, smooth and convex with an entire edge, and beige to pinkish depending on the age of the colonies. Cells are able to grow at mesophilic temperatures. Optimal growth is observed at $37^{\circ} \mathrm{C}$. Denitrifies nitrate to nitrite and nitrite to $\mathrm{N}_{2}$. Exhibits cytochrome oxidase, catalase and gelatinase activity, and produces hydrogen sulfide from thiosulfate. Haemolyses sheep blood cells and does not grow at $\mathrm{NaCl}$ concentrations above $3 \%$. Utilizes acetate, succinate, fumarate and citrate as sole carbon sources as well as a few carbohydrates and amino acids. Very active in the reduction of iron, manganese and sulfur compounds. Strain SB2 ${ }^{\mathrm{T}}$ was isolated from intertidal sediments. The $\mathrm{G}+\mathrm{C}$ content of the DNA is $51.7 \mathrm{~mol} \%$. The type strain, SB2B ${ }^{\mathrm{T}}$, has been deposited with the American Type Culture Collection as ATCC $700329^{\mathrm{T}}$.

\section{ACKNOWLEDGEMENTS}

We thank B. MacGregor and K. Reed for assistance with the phylogenetic analyses and C. Wimpee and S. M. Rea, for providing DNA of some of the Shewanella strains. Our thanks are due to $H$. Owen for the help with the electron microscopy and Jutta Burghardt for DNA-DNA hybridization analysis. We are thankful to D. Moser for critically reading this manuscript. This work was supported by NASA (144-GH82) and SEA (144-FP99) grants to K.H.N and for field sampling by NSF OCE 94156111 to R.C.A.

\section{REFERENCES}

Aller, R. C., Mackin, J. E. \& Cox, R. T., Jr (1986). Diagenesis of Fe and $\mathrm{S}$ in Amazon inner shelf muds: apparent dominance of $\mathrm{Fe}$ reduction and implications for the genesis of ironstones. Cont Shelf Res 6, 263-289.

Aller, R. C., Aller, J. Y., Michalopoulos, P. \& Green, M. A. (1997). Biogeochemical processes in coastal mobile mud belts derived from the Amazon River. Abstract no. 81. Santa Fe, NM: American Society for Limnology and Oceanography.

Aller, R. C., Blair, N. E., Xia, Q. \& Rude, P. D. (1996). Remineralization rates, recycling, and storage of carbon in Amazon shelf sediments. Cont Shelf Res 16, 753-786.

Allison, M. A., Nittrouer, C. A. \& Faria, L. E. C., Jr (1995). Rates and mechanisms of shoreface progradation and retreat downdrift of the Amazon river mouth. Mar Geol 125, 373-392.

Atkinson, R. J., Posner, A. M. \& Guirk, J. P. (1967). Adsorption of potential-determining ions at the ferric oxide-aqueous electrolyte interface. J Phys Chem 71, 550-558.

Bowman, J. P., McCammon, S. A., Nichols, D. S., Skerratt, J. H., Rea, S. M., Nichols, P. D. \& McMeekin, T. A. (1997). Shewanella gelidimarina sp. nov., and Shewanella frigidimarina sp. nov., novel Antarctic species with the ability to produce eicosapentaenoic acid $(20: 5 \omega 3)$ and grow anaerobically by dissimilatory Fe(III) reduction. Int $J$ Syst Bacteriol 47, 1040-1047.

Burdige, D. J. \& Nealson, K.H. (1986). Chemical and microbiological studies of sulfide-mediated manganese reduction. Geochem J 4, 365-368.

Cashion, P., Holder-Franklin, M. A., McCully, J. \& Franklin, M. (1977). A rapid method for the base ratio determination of bacterial DNA. Anal Biochem 81, 461-466.

Cole, R. M. \& Popkin, T. J. (1981). Electron microscopy. In Manual of Methods for General Bacteriology, pp. 34-51. Edited by P. Gerhardt, R. G. E. Murray, R. N. Costilaw, E. W. Nester, 
W. A. Wood, N. R. Krieg \& G. B. Phillips. Washington, DC: American Society for Microbiology.

De Ley, J., Cattoir, H. \& Reynaerts, A. (1970). The quantitative measurement of DNA hybridisation from renaturation rates. Eur J Biochem 12, 133-142.

Escara, J. F. \& Hutton, J. R. (1980). Thermal stability and renaturation of DNA in dimethylsulphoxide solutions: acceleration of renaturation rate. Biopolymers 19, 1315-1327.

Fonnesbech-Vogel, B., Jorgensen, K., Christensen, H., Olsen, J. E. \& Gram, L. (1997). Differentiation of Shewanella putrefaciens and Shewanella alga on the basis of whole-cell protein profiles, ribotyping, phenotypic characterization, and 16S rRNA gene sequence analysis. Appl Environ Microbiol 63, 2189-2199.

Huá, V. A. R., Festl, H. \& Schleifer, K. H. (1983). Studies on the spectrophotometric determination of DNA hybridization from renaturation rates. Syst Appl Microbiol 4, 184-192.

Jahnke, K.-D. (1992). BASIC computer program for evaluation of spectroscopic DNA renaturation data from GILFORD SYSTEM 2600 spectrophotometer on a PC/XT/AT type personal computer. J Microbiol Methods 15, 61-73.

Jensen, M. J., Tebo, B. M., Baumann, P., Mandel, M. \& Nealson, K. H. (1980). Characterization of Alteromonas hanedai (sp. nov.), a nonfermentative luminous species of marine origin. Curr Microbiol 3, 311-315.

Johnson, J. L. (1981). Genetic characterization. In Manual of Methods for General Bacteriology, pp. 450-472. Edited by P. Gerhardt, R. G. E. Murray, R. N. Costilaw, E. W. Nester, W. A. Wood, N. R. Krieg \& G. B. Phillips. Washington, DC: American Society for Microbiology.

Kuehl, S. A., Nittrouer, C. A. \& DeMaster, D. J. (1986). Nature of sediment accumulation on the Amazon continental shelf. Cont Shelf Res 6, 209-225.

Lovely, D. R. \& Phillips, E. J. (1988). Novel mode of microbial energy metabolism: organic carbon oxidation coupled to dissimilatory reduction of iron or manganese. Appl Environ Microbiol 51, 683-689.

MacDonnell, M. T. \& Colwell, R. R. (1985). Phylogeny of the Vibrionaceae and recommendation for two new genera, Listonella and Shewanella. Syst Appl Microbiol 6, 171-182.

Makemson, J. C., Fulayfil, N. R., Landry, W., Van Ert, L. M., Wimpee, C. F., Widder, E. A. \& Case, J. F. (1997). Shewanella woodyi sp. nov., an exclusively respiratory luminous bacterium isolated from the Alboran Sea. Int $J$ Syst Bacteriol 47, 1034-1039.

Mesbah, M., Premachandran, U. \& Whitman, B. (1989). Precise measurement of the $\mathrm{G}+\mathrm{C}$ content of deoxyribonucleic acid by high-performance liquid chromatography. Int $J$ Syst Bacteriol 39, 159-167.

Meyers, C. R. \& Nealson, K. H. (1988). Bacterial manganese reduction and growth with manganese oxide as the sole electron acceptor. Science 240, 1319-1321.

Moser, D. P. \& Nealson, K. H. (1996). Growth of the facultative anaeobe Shewanella putrefaciens by elemental sulfur reduction. Appl Environ Microbiol 62, 2100-2105.

Moss, C. W., Lambert, M. A. \& Merwin, W. H. (1974). Comparison of rapid methods for analysis of bacterial fatty acids. Appl Microbiol 28, 80-85.
Nealson, K. H. \& Saffarini, D. (1994). Iron and manganese anaerobic respiration. Annu Rev Microbiol 48, 311-343.

Nealson, K. H., Meyers, C. R. \& Wimpee, B. B. (1991). Isolation and identification of manganese-reducing bacteria and estimates of microbial $\mathrm{Mn}(\mathrm{IV})$-reducing potential in the Black Sea. Deep Sea Res 38, S907-S920.

Owen, R. J., Legros, R. M. \& Lapage, S. P. (1978). Base composition, size, and sequence similarities of genome deoxyribonucleic acids from clinical isolates of Pseudomonas putrefaciens. J Gen Microbiol 104, 127-138.

Ruimy, R., Breittmayer, V., ElBaze, P., Lafay, B., Boussemart, O., Gauthier, M. \& Christen, R. (1994). Phylogenetic analysis and assessment of the genera Vibrio, Photobacterium, Aeromonas, and Plesiomonas deduced from small-subunit rRNA sequences. Int $J$ Syst Bacteriol 44, 416-426.

Sambrook, J., Fritsch, E. F. \& Maniatis, T. (1989). Molecular Cloning: a Laboratory Manual, 2nd edn. Cold Spring Harbor, NY: Cold Spring Harbor Laboratory.

Semple, K. M. \& Westlake, D. W. S. (1987). Characterization of iron reducing Alteromonas putrefaciens strains from oil field fluids. Can J Microbiol 35, 925-931.

Simidu, U., Kita-Tsukamoto, K., Yasumoto, T. \& Yotsu, M. (1990). Taxonomy of four marine bacterial strains that produce tetrodotoxin. Int J Syst Bacteriol 40, 331-336.

Stackebrandt, E. \& Goebel, B. M. (1994). A place for DNA-DNA reassociation and $16 \mathrm{~S}$ rRNA sequence analysis in the present species definition in bacteriology. Int $J$ Syst Bacteriol 44, 846-849.

Stenstrom, I.-M. \& Molin, G. (1990). Classification of spoilage flora of fish, with special reference to Shewanella putrefaciens. $J$ Appl Bacteriol 68, 601-618.

Strunk, O. \& Ludwig, W. (1995). ARB - a software environment for sequence data. Department of Microbiology, Technical University of Munich, Munich, Germany.

Swofford, D. (1990). PAUP: phylogenetic analysis using parsimony, version 3.0. Computer program distributed by the Illinois Natural History Survey, Champaign, IL, USA.

Truper, H. G. \& de' Clari, L. (1997). Taxonomic note: necessary correction of specific epithets formed as substantives (nouns) 'in apposition'. Int J Syst Bacteriol 47, 908-909.

Venkateswaran, K., Nakano, H., Okabe, T., Takayama, K., Matsuda, O. \& Hashimoto, H. (1989). Occurrence and distribution of Vibrio spp., Listonella spp., and Clostridium botulinum in the Seto Inland Sea of Japan. Appl Environ Microbiol 55, 559-567.

Wayne, L. G., Brenner, D. G., Colwell, R. R. \& 9 other authors (1987). International Committee on Systematic Bacteriology. Report of the ad hoc committee on reconciliation of approaches to bacterial systematics. Int J Syst Bacteriol 37, 463-464.

West, P. A. \& Colwell, R. R. (1984). Identification and classification overview. In Vibrios in the Environment, pp. 285-363. Edited by R. R. Colwell. New York: Wiley.

Woese, C. R. (1987). Bacterial evolution. Microbiol Rev 51, 221-271.

Yamamoto, S. \& Harayama, S. (1995). PCR amplification and direct sequencing of $g y r B$ genes with universal primers and their application to the detection and taxonomic analysis of Pseudomonas putida strains. Appl Environ Microbiol 61, 1104-1109. 